\title{
Pengaruh Perubahan Luas Bukaan Katup untuk Air Keluar dari Dalam Tangki pada Sistem Pengendalian Tinggi Muka Air
}

\section{The Effect of Changing The Output Valve Opening Area on The Water Level Control System}

\author{
Iwan Rohman Setiawan ${ }^{*}$, Aris Munandar ${ }^{2}$ \\ ${ }^{1,2}$ Balai Pengembangan Instrumentasi - Lembaga Ilmu Pengetahuan Indonesia \\ Komplek LIPI, Gedung 30, Jl. Sangkuriang, Bandung 40135 \\ Iwanrs007@gmail.com ${ }^{1 *}$, arezmr@gmail.com ${ }^{2}$
}

\begin{abstract}
Abstrak - Paper ini membahas pengaruh perubahan luas bukaan katup keluaran terhadap level air dalam tangki. Simulasi dilakukan pada mini plant sistem pengendalian tinggi muka air di dalam tangki menggunakan sistem pengendalian bertingkat atau umpan balik single loop menggunakan pengendali PID. Berdasarkan simulasi, ketika level pada steady state 0,5998 m, dengan tidak mengubah parameter pengendali PID, apabila katup dibuka hingga luas lubang untuk air keluar bertambah dari 5,3434 $\times 10^{-5}$ $\mathrm{m}^{2}$ sampai maksimum $7,1220 \times 10^{-5} \mathrm{~m}^{2}$, terjadi steady state error ketinggian air terhadap set point sebesar 3,17\%. Jika menggunakan sistem pengendalian bertingkat, ketika katup ditutup hingga luas lubang semakin kecil dari 5,3434 × $10^{-5} \mathrm{~m}^{2}$, maka steady state error mulai terjadi ketika luas bukaan katup 3,4236 $x 10^{-5} \mathrm{~m}^{2}$, dengan nilai eror sebesar $-5,2337 \%$. Sementara jika menggunakan sistem pengendalian umpan balik single loop, error mulai terjadi ketika luas bukaan katup 2,9172 $\times 10^{-5} \mathrm{~m}^{2}$, dengan eror sebesar $15,45 \%$.
\end{abstract}

Kata Kunci: Sistem pengendalian bertingkat, sistem pengendalian umpan balik single loop, tinggi muka air, perubahan luas bukaan katup, error.

\begin{abstract}
This paper discusses the effect of changing the area of the output valve opening to the water level in the tank. Simulation is carried out on a mini plant of water level control system in the tank using a cascade control system or single loop feedback using PID controllers. Based on the simulation, when the level at steady state is $0.5998 \mathrm{~m}$, by not changing the PID controller parameters, if the valve is opened until the output hole area increases from $5.3434 \times 10-5 \mathrm{~m}^{2}$ to a maximum of $7.1220 \times 10^{-5} \mathrm{~m}^{2}$, occurs steadystate error of water level against setpoint is $3.17 \%$. Whereas when the valve is closed until the hole area is smaller than $5.3434 \times 10^{-5} \mathrm{~m}^{2}$, then for the cascade control system, steady state error start to occur when the valve opening area is $3.4236 \times 10^{-5} \mathrm{~m}^{2}$, which is equal to $-5.2337 \%$. In the single loop feedback control system, the error begins when the valve opening area is $2.9172 \times 10^{-5} \mathrm{~m}^{2}$, which is $-15.45 \%$.
\end{abstract}

Keywords: Multilevel control system, single loop feedback control system, water level, valve opening width variance, error.

TELKA, Vol.5, No.1, Mei 2019, pp. 31 42

ISSN (e): 2540-9123

ISSN (p): 2502-1982 


\section{Pendahuluan}

Pengendalian tinggi muka zat cair (level) adalah salah satu aspek yang banyak diterapkan pada plant di industri proses, seperti industri minyak dan gas, industri kimia, perlindungan lingkungan, pengolahan air, metalurgi dan industri lainnya. Adapun contoh aplikasi pengendalian level di industri proses diantaranya pengendalian tinggi muka zat cair di dalam tangki bertekanan. Tujuan dari pengendalian tinggi muka zat cair adalah untuk memastikan kualitas dan kuantitas bahan baku, produk setengah jadi, atau produk jadi di dalam kontainer dengan memeriksa dan menyesuaikan keseimbangan antara masukan dan keluaran material dari kontainer [1]. Selanjutnya, pada sistem pengendalian zat cair dapat terjadi gangguan yang ditimbulkan oleh perubahan besarnya debit zat cair yang mengalir menuju tangki, atau perubahan debit zat cair yang keluar dari dalam tangki [2]-[4].

Tulisan ini merupakan kelanjutan dari tulisan penulis [2], dimana pada tulisan tersebut dengan menggunakan simulink telah dibuat simulasi terjadi gangguan pada sistem kendali tinggi muka air di dalam tangki menggunakan pengendali PID, dengan sistem pengendalian bertingkat, juga sistem pengendalian umpan balik single loop. Simulasi gangguan yaitu terjadi peningkatan dan penurunan debit air yang menuju ke dalam tangki dengan asumsi sebanyak $1,667 \times 10^{-5}$ $\mathrm{m}^{3} /$ detik, gangguan tersebut terjadi ketika tinggi muka air di dalam tangki dalam keadaan stabil pada set point $0,3 \mathrm{~m}$. Hasil dari simulasi diperoleh bahwa, dengan tidak mengubah parameter pengendali PID, ketika terjadi penambahan atau pengurangan debit air yang menuju ke dalam tangki pada sistem kendali tinggi muka air dengan sistem pengendalian bertingkat, tidak mempengaruhi tinggi muka air di dalam tangki, sedangkan pada sistem pengendalian single loop terjadi kenaikan atau penurunan tinggi muka air di dalam tangki, sampai akhirnya tinggi muka air di dalam tangki kembali stabil pada set pointnya [2], [5]-[6].

Pada makalah ini, melalui simulasi menggunakan simulink, dilakukan penyelidikan akibat gangguan yang terjadi pada mini plant sistem pengendalian tinggi muka air di dalam tangki menggunakan pengendali PID, dengan sistem pengendalian bertingkat, juga sistem pengendalian umpan balik single loop. Gangguan yang terjadi yaitu, ketika tinggi muka air di dalam tangki dalam keadaan stabil pada set point nya, lalu terjadi perubahan luas bukaan katup untuk air keluar dari dalam tangki. Perubahan luas bukaan katup dilakukan dengan tanpa mengubah parameter pengendali PID. Selanjutnya membandingkan pengaruh gangguan akibat perubahan luas bukaan katup untuk air keluar dari dalam tangki, antara sistem pengendalian bertingkat dengan sistem pengendalian umpan balik single loop.

\section{Metode Penelitian}

Mini plant sistem pegendalian tinggi muka air di dalam tangki menggunakan pengendali PID. Mini plant difungsikan untuk sistem pegendalian tinggi muka air di dalam tangki-umpan balik single loop, atau dengan sistem pengendalian bertingkat (LC-FC). Level controller (LC) berfungsi sebagai master controller sedangkan flow controller (FC) sebagai slave controller. Keluaran dari LC menjadi setpoint untuk FC seperti diperlihatkan pada gambar Piping \& Instrumentation Diagram (P\&ID) di Gambar 1. 


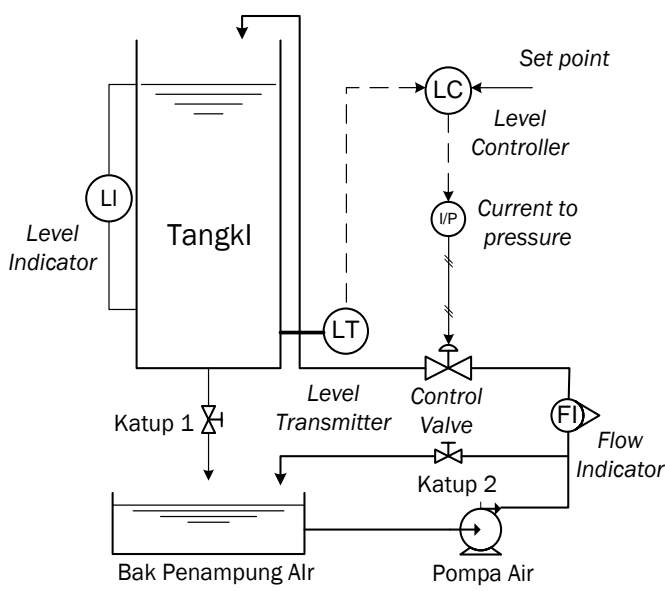

(a) Sistem pengendalian umpan balik single loop [5-6].

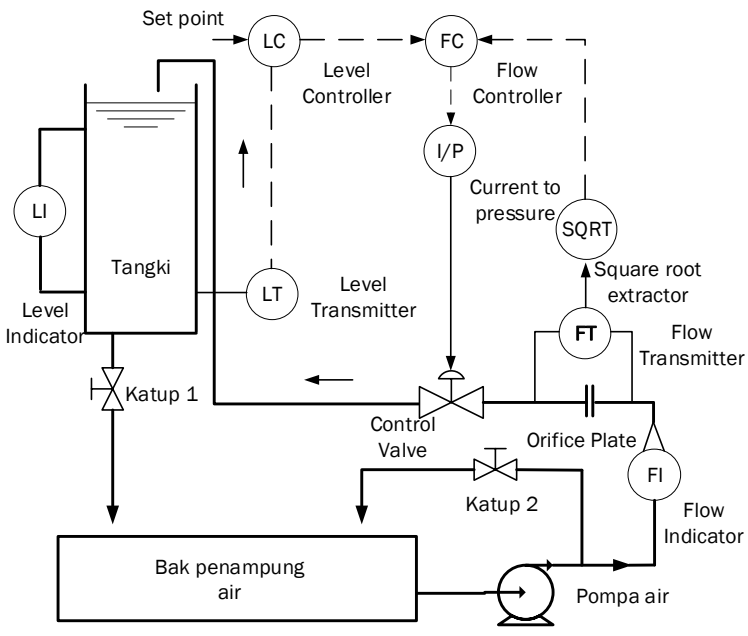

(b). Sistem Pengendalian Bertingkat (LC-FC) [5-6]

Gambar 1. P\&ID Mini Plant Sistem Pegendalian Tinggi Muka Air di Dalam Tangki

Adapun desain dan instrumen-instrumen mini plant seperti diperlihatkan pada Tabel 1.

Tabel 1. Desain dan instrumen mini plant [6].

\begin{tabular}{|c|c|c|}
\hline No. & Desain dan Instrumen & Ukuran/spesifikasi \\
\hline 1 & Tinggi tangka & 1,25 meter \\
\hline 2 & $\begin{array}{l}\text { Tinggi maksimum pengukuran muka air di dalam } \\
\text { tangki (LH) }\end{array}$ & 0,8 meter \\
\hline 3 & $\begin{array}{l}\text { Tinggi minimum pengukuran muka air di dalam tangki } \\
\text { (LL) }\end{array}$ & 0,2 meter \\
\hline 4 & Diameter tangki (D) & 0,25 meter \\
\hline 5 & Debit maksimum aliran air menuju tangki (Q) & $3,154 \times 10^{-4} \mathrm{~m}^{3} /$ detik $\approx 19$ liter $/$ menit \\
\hline 6 & Diameter pipa untuk air keluar dari dalam tangki (d) & 0,5 inci \\
\hline 7 & Level Transmitter (LT) & $\begin{array}{l}\text { Input } 0-100 \mathrm{IN} \mathrm{H}_{2} \mathrm{O} \\
\text { Output } 4-20 \mathrm{~mA}\end{array}$ \\
\hline 8 & Flow Transmitter (FT) & $\begin{array}{l}\text { Input } 0-150 \mathrm{IN} \mathrm{H}_{2} \mathrm{O} \\
\text { Output } 4-20 \mathrm{~mA}\end{array}$ \\
\hline 9 & Current to pressure $(\mathrm{I} / \mathrm{P})$ & $\begin{array}{l}\text { Input } 0,2-1 \mathrm{bar} \\
\text { Output } 4-20 \mathrm{~mA}\end{array}$ \\
\hline 10 & Control valve & Diameter 0,5 inci \\
\hline 11 & Diameter dalam plat orifice $(\mathrm{d})$ & 0,34 inci \\
\hline 12 & $\begin{array}{l}\text { Pengendali: } \\
\text { a. Level Controller (LC) } \\
\text { b. Flow Controller (FC) }\end{array}$ & $\begin{array}{l}\text { Proportional, Integral, Derivative (PID). } \\
\text { Output } 4-20 \mathrm{~mA} \text {. }\end{array}$ \\
\hline
\end{tabular}

Model hubungan antara debit air yang masuk ke dalam tangki, $q_{\text {in }}\left(\mathrm{m}^{3} /\right.$ detik) dengan debit air keluar dari dalam tangki, $q_{\text {out }}\left(\mathrm{m}^{3} /\right.$ detik) dan tinggi muka air di dalam tangki, $h(\mathrm{~m})$, dalam keadaan setimbang dimodelkan melalui gravity flow tank model [3], [7]-[8], seperti diperlihatkan di Gambar 2. 


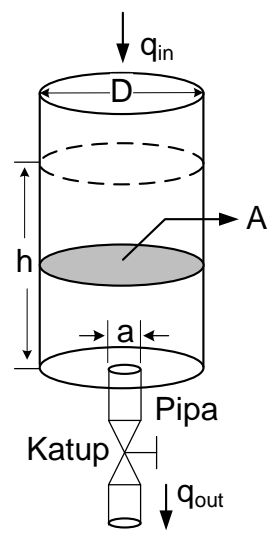

Gambar 2. Gravity flow tank model [7-8].

dengan $a$ adalah luas lubang untuk air keluar dari dalam tangki $\left(\mathrm{m}^{2}\right), A$ adalah luas tangki $\left(\mathrm{m}^{2}\right)$ dan $D$ adalah diameter tangki (m).

Selanjutnya dari Gambar 2, debit air yang keluar dari dalam tangki adalah [7]-[9]

$$
q_{\text {out }}=a v=a \sqrt{2 g h},
$$

dengan $v$ adalah kecepatan air (m/detik), $g$ percepatan gravitasi $=9,8 \mathrm{~m} / \mathrm{detik}^{2}$.

Persamaan (1) memperlihatkan bahwa besarnya $q_{\text {out }}$ bergantung terhadap tinggi muka air di dalam tangki $(h)$. Model lengkap diperoleh apabila diketahui akibat air yang masuk ke dalam tangka $\left(q_{\text {in }}\right)$, terhadap tinggi muka air di dalam tangka $(h)$. Nilai $h$ merepresentasikan energi potensial dari sistem dan dinyatakan sebagai suatu variabel keadaan (state variable). Apabila air masuk ke dalam tangki $\left(q_{\text {in }}\right)$, maka tinggi muka air di dalam tangka $(h)$ naik, lalu apabila air mengalir keluar dari dalam tangka $\left(q_{\text {out }}\right)$, maka tinggi muka air di dalam tangka $(h)$ menurun. Dalam bentuk matematika dijelaskan melalui persamaan diferensial sebagai berikut [7]

$$
\frac{d V}{d t}=q_{\text {in }}-q_{\text {out }},
$$

dengan $V$ adalah volume air $\left(\mathrm{m}^{3}\right)$. Selanjutnya, karena volume air di dalam tangka $(V)$, bergantung terhadap tinggi muka air di dalam tangki $(h)$, maka

$$
\frac{d V}{d t}=\frac{d}{d t}(A h)=A \frac{d h}{d t}=q_{\text {in }}-q_{\text {out }} .
$$

Lalu substitusi (1) ke (3), maka diperoleh

$$
A \frac{d h}{d t}=q_{i n}-a \sqrt{2 g h} .
$$

Persamaan (4) dituliskan kembali menjadi

$$
A \frac{d h}{d t}+\sqrt{2 g} a \sqrt{h}=q_{\text {in }} .
$$

Selanjutnya untuk tujuan simulasi, maka (5) dituliskan kembali menjadi

$$
\frac{d h}{d t}=\frac{q_{\text {in }}}{A}-\frac{a}{A} \sqrt{2 g h}
$$


Lalu, dengan menggunakan kurva hasil simulasi dari (6) diperoleh penguatan tangki, K, yaitu [910]

$$
K=\frac{\Delta h}{\Delta q_{\text {in }}},
$$

dengan $\Delta h$ adalah perubahan keluaran tinggi muka air keadaan steady (steady state), $\Delta q_{\text {in }}$ perubahan masukan debit air keadaan steady.

Steady state penting untuk operasi proses, steady state muncul apabila semua sinyal, khususnya variabel keadaan tetap konstan, sehingga dengan menyelesaikan persamaan keadaan, dimana untuk kasus ini semua nilai derivatif adalah 0 [7], maka (4) menjadi [7]

$$
0=q_{\text {in }}-a \sqrt{2 g h} .
$$

Selanjutnya dari (3) dan (4), karena $\mathrm{q}_{\text {out }}=\mathrm{a} \sqrt{2 \mathrm{gh}}$ maka (8) dituliskan menjadi

$$
q_{\text {out }}=q_{\text {in }},
$$

dengan $\mathrm{q}_{\text {out }}$ adalah debit air keluar dari tangki dalam keadaan steady dan $\mathrm{q}_{\text {in }}$ masukan debit air ke tangki dalam keadaan steady.

Apabila $q_{\text {in }}$ dalam keadaan steady, maka tinggi muka air di dalam tangki akan mencapai keadaan steady, sehingga (8) menjadi

$$
h_{S S}=\frac{q_{i n}^{2}}{2 g a^{2}}
$$

dengan $h_{s s}$ adalah tinggi muka air dalam keadaan steady.

Persamaan (6) adalah model non linier, untuk melinierkan (6), maka (6) dilinierkan di titik kesetimbangannya [7], [11], yaitu $q_{\text {in_ss }}$ dan $h_{s s}$, (ss menunjukan nilai steady state), sehingga (6) menjadi [7]

$$
\frac{d \Delta h}{d t}=\frac{\Delta q_{i n}}{A}-\frac{a \sqrt{2 g}}{2 A \sqrt{h_{S S}}} \Delta h .
$$

Karena $d / d t=s(s$ adalah operator transformasi Laplace) dan dengan asumsi $\Delta h(0)=0$, maka (11) menjadi

$$
s \Delta h=\frac{\Delta q_{i n}}{A}-\frac{a \sqrt{2 g}}{2 A \sqrt{h_{s S}}} \Delta h .
$$

Dari (12), penyelesaian persamaan aljabar untuk $\Delta h(\mathrm{~s})$ diperoleh sebagai berikut,

$$
\Delta h=\frac{\frac{1}{A}}{s+\frac{a \sqrt{2 g}}{2 A \sqrt{h_{s s}}}} \Delta q_{i n} .
$$

Selanjutnya dari (13) diperoleh fungsi alih G(s) yaitu,

$$
G(s)=\frac{\frac{\sqrt{2 h_{S s}}}{a \sqrt{g}}}{\frac{A \sqrt{2 h_{S S}}}{a \sqrt{g}} S+1} .
$$

Sehingga (14) dituliskan menjadi sebagai berikut, 


$$
\sqrt{h_{s s}}=\frac{q_{\text {in_ss }}}{a \sqrt{2 g}}
$$

Selanjutnya (14) dinyatakan dalam bentuk $q_{i n_{-} s s}$ dengan subtitusi (15) ke (14), sehingga diperoleh fungsi alih sebagai berikut,

$$
G(s)=\frac{\frac{q_{\text {in_ss }}}{a^{2} g}}{\frac{A q_{\text {in_ss }} s}{a^{2} g}+1} .
$$

Karena (16) adalah bentuk umum fungsi alih orde satu, maka dapat dituliskan menjadi

$$
G(s)=\frac{K}{T s+1},
$$

dengan $\mathrm{K}$ adalah penguatan dan $\tau$ adalah konstanta waktu (detik), dimana

$$
K=\frac{q_{\text {in_ss }}}{a^{2} g} \text {. }
$$

Dengan

maka,

$$
\tau=A \frac{q_{i n s s}}{a^{2} g}
$$

$$
\tau=A K
$$

Hubungan antara masukan debit air $\left(q_{\text {in }}\right)$, model tangki $(G)$, dan keluaran tinggi muka air $(h)$ dalam bentuk diagram blok diperlihatkan pada Gambar (3) [7], [11].

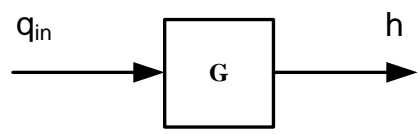

Gambar 3. Hubungan antara masukan debit air, model tangki dan tinggi muka air.

Berdasarkan Gambar 3, persamaan hubungan antara masukan debit air, model tangki dan keluaran tinggi muka air adalah sebagai berikut,

$$
h=G q_{\text {in }} .
$$

Berdasarkan hasil simulasi, dilakukan koreksi terhadap (18) menjadi,

$$
K=\frac{q_{\text {in_ss }}}{a^{2} g} c,
$$

dimana $c=1 / 2$.

\section{Hasil dan Pembahasan}

Pada bab ini dibahas mengenai pemodelan, simulasi dan pembahasan dari sistem pengendalian tinggi muka air dengan variasi ukuran bukaan katup keluaran.

\subsection{Menentukan Luas Bukaan Katup dan Penguatan Tangki}

Berdasarkan desain mini plant seperti diperlihatkan pada Gambar 1, Gambar 2 dan Tabel 1, selanjutnya tinggi air keadaan steady di dalam tangki ditetapkan $h_{s s}=0,6 \mathrm{~m}$, debit air yang masuk ke dalam tangki ditetapkan sebanyak $q_{i n}=1,8333 \times 10^{-4} \mathrm{~m}^{3} /$ detik. Dengan menggunakan (10) untuk memperoleh luas lubang untuk air keluar dari dalam tangki $(a)$, melalui bukaan katup 1 di 
Gambar 2, atau seperti dijelaskan juga melalui bukaan katup di Gambar 3, maka diperoleh luas lubang untuk air keluar dari dalam tangki, $a$, yaitu, $a=5,3434 \times 10^{-5} \mathrm{~m}^{2}$.

Berdasarkan (6), dilakukan simulasi untuk luas bukaan katup, $a=5,3434 \times 10^{-5} \mathrm{~m}^{2}$, luas tangki $A$ $=0,0449 \mathrm{~m}^{2}$ dan $q_{\text {in }}=1,8333 \times 10^{-4} \mathrm{~m}^{3} /$ detik. Hasil simulasi diperlihatkan pada Gambar 4.

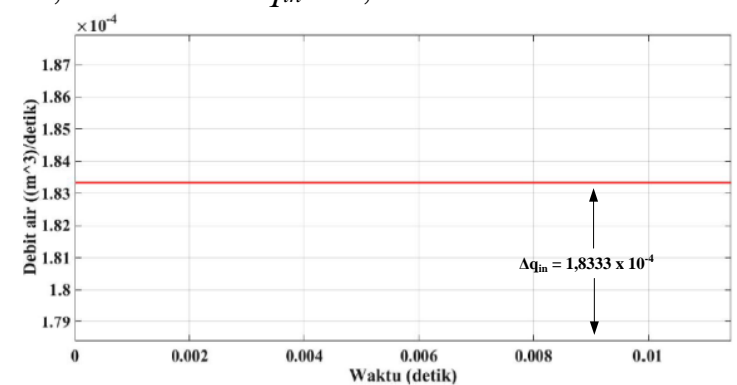

a. Masukan debit air

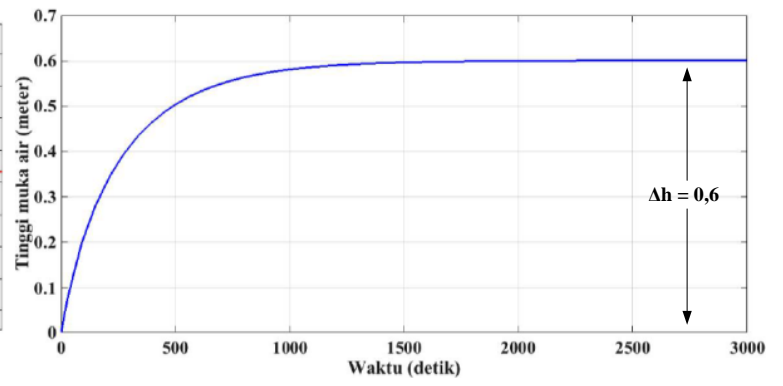

b. Keluaran tinggi muka air

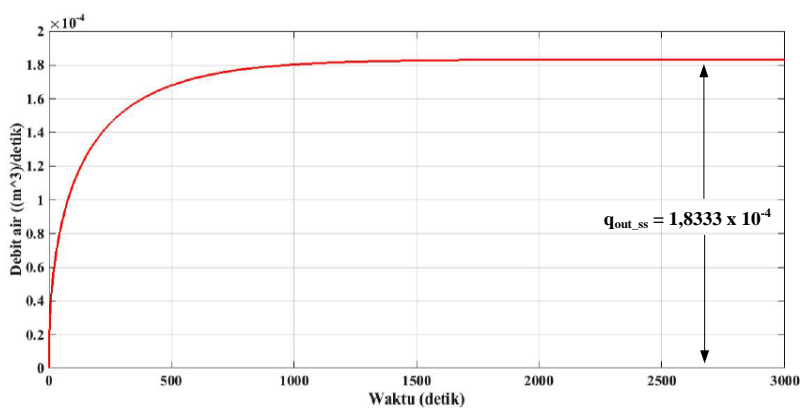

c. Debit air keluar dari dalam tangki

Gambar 4. Hasil simulasi hubungan antara masukan debit air, keluaran tinggi muka air di dalam tangki dan keluaran debit air menggunakan model non linier.

Gambar 4(a) memperlihatkan masukaan keadaan steady debit air ke tangki $\Delta q_{\text {in }}=1,8333 \mathrm{x}$ $10^{-4} \mathrm{~m}^{3} /$ detik yang mengakibatkan kenaikan tinggi muka air di dalam tangki dan mencapai steady state pada ketinggian 0,6 m, sebagaimana diperlihatkan pada Gambar 4(b). Selanjutnya $\Delta h=0,6$ $\mathrm{m}$ dan $\Delta q_{\text {in }}=1,8333 \times 10^{-4} \mathrm{~m}^{3} /$ detik disubtitusikan ke (7) maka diperoleh penguatan tangki yaitu $K=3272,7332 \mathrm{detik} / \mathrm{m}^{2}$

Gambar 4(c) memperlihatkan besarnya debit air yang keluar dari tangki dalam keadaan steady $\left(q_{\text {out_ss }}\right)=1,8333 \times 10^{-4} \mathrm{~m}^{3} /$ detik, dimana besarnya $q_{\text {out_ss }}$ sama dengan debit air yang masuk ke dalam tangka $\left(\Delta q_{i n}\right)$ dalam keadaan steady.

\subsection{Pemodelan Tangki}

Untuk memperoleh model tangki maka subtitusikan $g=9,8 \mathrm{~m} / \mathrm{detik}^{2}, q_{\text {in_ss }}=1,8333 \times 10^{-4}$ $\mathrm{m}^{3} /$ detik dan $a=5,3434 \times 10^{-5} \mathrm{~m}^{2}$ masing-masing ke (18), sehingga diperoleh penguatan, $K=$ $6545,4664 \mathrm{detik} / \mathrm{m}^{2}$. Nilai penguatan $(K)$, hasil dari (18) berbeda dengan nilai penguatan $(K)$, hasil dari (7), dimana (7) diperoleh berdasarkan hasil simulasi menggunakan (6).

Selanjutnya subtitusikan $K=6545,4664 \mathrm{detik} / \mathrm{m}^{2}$ dan luas tangki $A=0,0491 \mathrm{~m}^{2}$ ke (19), maka diperoleh konstanta waktu $\tau=321,1369$ detik. Selanjutnya nilai $K$ dan $\tau$ tersebut disubtitusikan ke (17) sehingga diperoleh model tangki yaitu,

$$
G(s)=\frac{6545,4664}{321,1369 s+1}
$$

Dalam bentuk diagram blok, hubungan antara masukan debit air dalam keadaan steady $\left(q_{\text {in_ss }}\right)$, model tangki $(G)$, dan keluaran tinggi muka air $(h)$, diperlihatkan pada Gambar 5. 


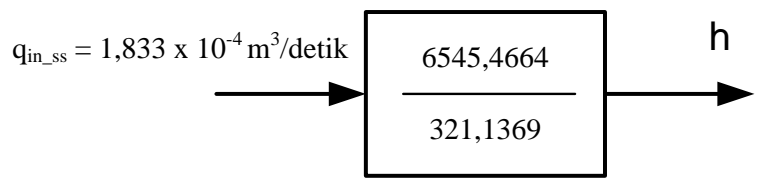

Gambar 5. Hubungan antara $q_{\text {in_ss }}$, model tangki dan keluaran tinggi muka air $(h)$.

Berdasarkan Gambar 5, selanjutnya dilakukan simulasi. Hasil simulasi diperlihatkan pada Gambar 6.

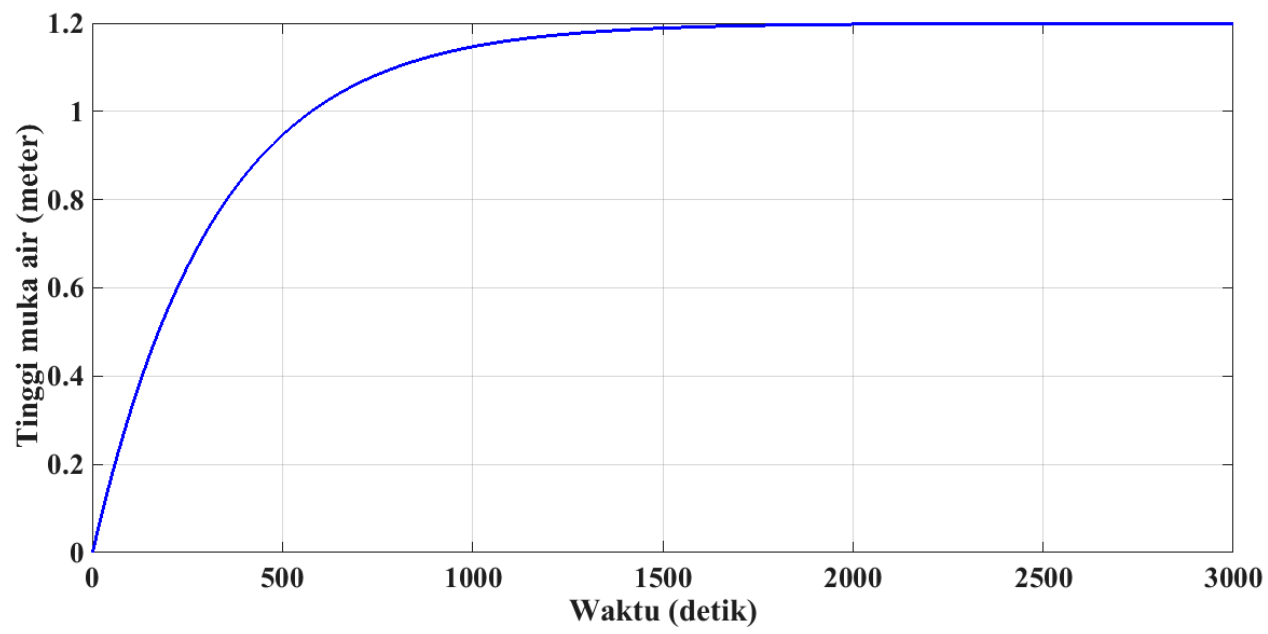

Gambar 6. Kurva tanggapan keluaran tinggi muka air di dalam tangki dengan penguatan $K=6545,4664 \mathrm{detik} / \mathrm{m}^{2}$ dan konstanta waktu $\tau=321,1369$ detik, terhadap masukan debit air $q_{\text {in_ss }}=1,8333 \times 10^{-4} \mathrm{~m}^{3} / \mathrm{detik}$.

Dari hasil simulasi seperti diperlihatkan pada Gambar 6, diperoleh keluaran tinggi muka air dalam keadaan steady, $h=1,2 \mathrm{~m}$, sedangkan tinggi muka air berdasarkan (6) adalah $h=0,6 \mathrm{~m}$.

Selanjutnya untuk nilai koreksi terhadap (18), diperoleh dengan membandingkan nilai penguatan dari hasil perhitungan menggunakan (7) dengan nilai penguatan dari hasil perhitungan menggunakan (18), yang hasilnya diperoleh nilai koreksi (c), untuk (18) yaitu,

$$
c=\frac{3272,7332 \mathrm{detik} / \mathrm{m} 2}{6545,4664 \mathrm{detik} / \mathrm{m} 2}=\frac{1}{2}
$$

Sehingga dengan subtitusi $q_{\text {in_ss }}=1,8333 \times 10^{-4} \mathrm{~m}^{3} /$ detik dan $a=5,3434 \times 10^{-5} \mathrm{~m}^{2}$ ke (22), diperoleh, $K=3272,7332 \mathrm{detik} / \mathrm{m}^{2}$. Selanjutnya subtitusikan nilai $K=3272,7332 \mathrm{detik} / \mathrm{m}^{2} \mathrm{dan} A$ $=0,0491 \mathrm{~m}^{2} \mathrm{ke}(20)$, maka diperoleh konstanta waktu $\tau=160,5685$ detik. Nilai $K=3272,7332$ $\operatorname{detik} / \mathrm{m}^{2}$ dan $\tau=160,5685$ detik selanjutnya disubtitusikan ke (17), sehingga diperoleh model tangki yaitu,

$$
G(s)=\frac{3272,7332}{160,5685 \mathrm{~s}+1}
$$

\subsection{Pengendalian Tinggi Muka Air Sebelum Terjadi Perubahan Luas Bukaan Katup}

Sistem kendali tinggi muka air di dalam tangki pada mini plant dalam bentuk diagram blok dan hasil pemodelannya diperlihatkan pada Gambar 7. 


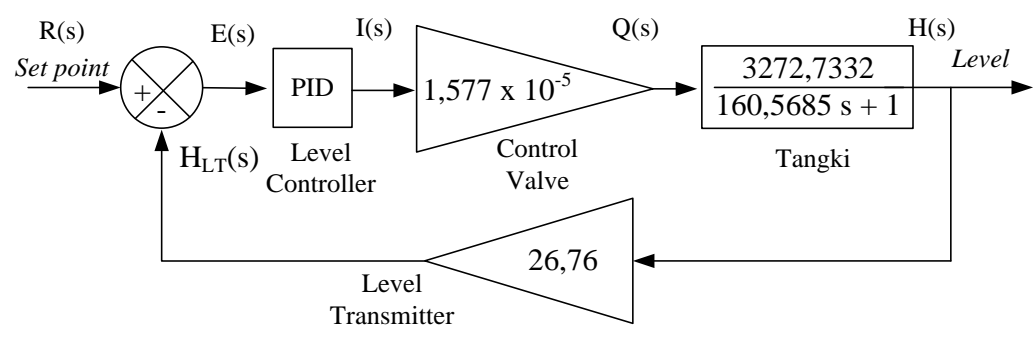

(a) Umpan balik -single loop [2], [12].

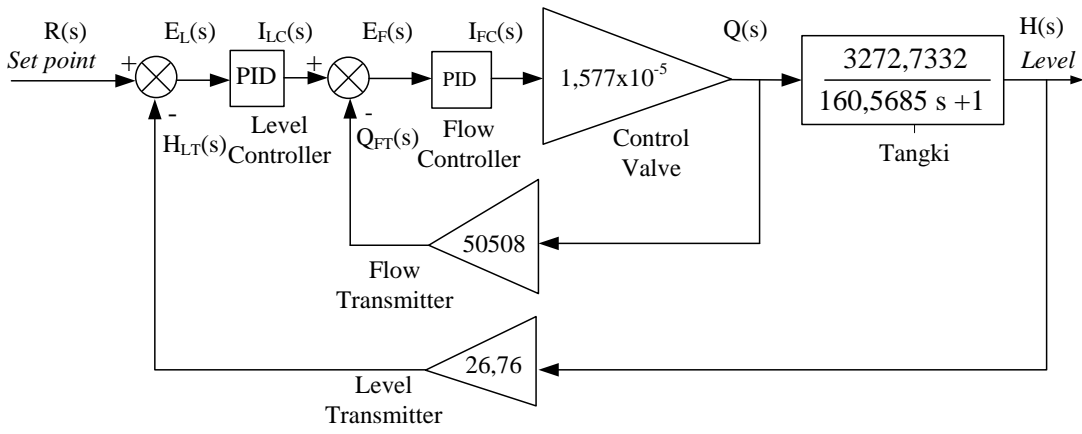

(b) Sistem pengendalian bertingkat [2], [12].

Gambar 7. Diagram blok sistem pengendalian tinggi muka air.

Berdasarkan skema pada Gambar 7(a) dan Gambar 7(b), karena set point tinggi muka air di dalam tangki $h=0,6 \mathrm{~m}$, maka nilai set point level controller (LC) adalah 16,0507 mA [6], [9]. Langkah selanjutnya adalah melakukan penalaan pengendali PID menggunakan simulink untuk LC pada Gambar 5(a), diperoleh $P=0,9547, I=0,0100, D=-31,8017$. Sedangkan berdasarkan Gambar 5(b), untuk LC diperoleh $P=1,1105, I=0,0088, D=-37,9007$ dan untuk flow controller (FC) diperoleh $P=0$ dan $I=0,1089$. Dari hasil simulasi diperoleh bahwa tinggi muka air di dalam tangki ketika mencapai steady state yaitu $h=0,5998 \mathrm{~m}$, sehingga steady state error $=$ $0,03 \%$. Pada tulisan ini steady state error yang diperkenankan maksimum $\pm 2 \%$ [11]. Settling time tinggi muka air untuk umpan balik single loop dicapai mulai pada detik ke 427, sedangkan untuk sistem pengendalian bertingkat mulai dicapai pada detik ke 349 [11].

\subsection{Model-Model Tangki Akibat Perubahan Luas Bukaan Katup}

Perubahan luas bukaan katup dari $a=5,3434 \times 10^{-5} \mathrm{~m}^{2}$ pada tulisan ini diasumsikan terjadi pada detik ke 1500, dimana pada detik ke 1500 tinggi muka air di dalam tangki dalam keadaan steady. Selanjutnya untuk memperoleh model-model tangki karena perubahan luas lubang untuk air keluar dari dalam tangki (a), akibat perubahan luas bukaan katup, dilakukan pendekatan yaitu berdasarkan (9), yaitu bahwa dalam keadaan steady besarnya debit air yang keluar dari dalam tangki sama dengan debit air yang masuk ke dalam tangki, seperti diperlihatkan pada Gambar 4(a) dan Gambar 4(c). Maka pada (22), besarnya debit air yang masuk ke dalam tangki pada keadaan steady, $q_{\text {in_ss, }}$ sama besarnya dengan debit air yang keluar dari dalam tangki dalam keadaan steady, qout_ss melalui katup, sehingga pada (22) besarnya debit air yang masuk ke dalam tangki ketika luas lubang katup berubah pada detik ke 1500, sama besarnya dengan debit air yang masuk ke dalam tangki ketika $a=5,3434 \times 10^{-5} \mathrm{~m}^{2}$ yaitu $q_{i n_{-} s s}=1,8333 \times 10^{-4} \mathrm{~m}^{3} /$ detik.

Selanjutnya perubahan luas lubang untuk air keluar dari dalam tangki akibat perubahan luas bukaan katup, ditinjau dengan menyelidiki perubahan luas lubang dari $a=5,3434 \times 10^{-5} \mathrm{~m}^{2}$ menjadi: $2,9172 \times 10^{-5} \mathrm{~m}^{2}, 3,1653 \times 10^{-5} \mathrm{~m}^{2}, 3,4236 \times 10^{-5} \mathrm{~m}^{2}, 3,5565 \times 10^{-5} \mathrm{~m}^{2}, 3,6920 \times 10^{-5} \mathrm{~m}^{2}$, $3,8300 \times 10^{-5} \mathrm{~m}^{2}, 4,5581 \times 10^{-5} \mathrm{~m}^{2}, 6,2040 \times 10^{-5} \mathrm{~m}^{2}, 6,5636 \times 10^{-5} \mathrm{~m}^{2}, 6,7472 \times 10^{-5} \mathrm{~m}^{2}, 6,9333$ 
x $10^{-5} \mathrm{~m}^{2}$ dan $7,1220 \times 10^{-5} \mathrm{~m}^{2}$, atau perubahan diameter lubang dari 0,32 inci, menjadi masingmasing: 0,24 inci, 0,25 inci, 0,26 inci, 0,265 inci, 0,27 inci, 0275 inci, 0,3 inci, 0,35 inci, 0,36 inci, 0,365 inci, 0,37 inci dan 0,375 inci, dengan $q_{\text {in_ss }}=1,8333 \times 10^{-4} \mathrm{~m}^{3} /$ detik. Setiap nilai tersebut disubtitusikan ke (22), sehingga diperoleh model-model tangki seperti diperlihatkan pada Tabel 2.

Tabel 2. Model-model tangki akibat perubahan luas lubang untuk air keluar dari dalam tangka.

\begin{tabular}{|c|c|c|c|c|c|}
\hline No. & $\begin{array}{c}\text { Diameter lubang, } \\
D \\
\text { (Incii) }\end{array}$ & $\begin{array}{l}\text { Luas lubang } \\
\text { katup, } a \\
\left(\mathrm{~m}^{2}\right)\end{array}$ & $\begin{array}{l}\text { Penguatan, K } \\
\left(\text { detik } / \mathrm{m}^{2}\right)\end{array}$ & $\begin{array}{c}\text { Konstanta } \\
\text { waktu, } \tau \\
\text { (detik) }\end{array}$ & $\begin{array}{l}\text { Model tangki, } \\
\qquad G(s)\end{array}$ \\
\hline 1 & 0,24 & $2,9172 \times 10^{-5}$ & 10980,5096 & 538,7313 & $\frac{10980,5096}{538,7313}$ \\
\hline 2 & 0,25 & $3,1653 \times 10^{-5}$ & 9326,2580 & 457,5695 & $\frac{9326,2580}{457,5695}$ \\
\hline 3 & 0,26 & $3,4236 \times 10^{-5}$ & 7972,1245 & 391,1324 & $\frac{7972,1245}{391,1324}$ \\
\hline 4 & 0,265 & $3,5565 \times 10^{-5}$ & 7387,2699 & 362,4379 & $\frac{7387,2699}{362,4379}$ \\
\hline 5 & 0,27 & $3,6920 \times 10^{-5}$ & 6855,0781 & 336,3273 & $\frac{6855,0781}{336,3273}$ \\
\hline 6 & 0,275 & $3,8300 \times 10^{-5}$ & 6369,9597 & 312,5261 & $\frac{6369,9597}{312,5261}$ \\
\hline 7 & 0,3 & $4,5581 \times 10^{-5}$ & 4497,6167 & 220,6643 & $\frac{4497,6167}{220,6643}$ \\
\hline 8 & 0,35 & $6,2040 \times 10^{-5}$ & 2427,7015 & 119.1091 & $\frac{2427,7015}{119.1091}$ \\
\hline 9 & 0,36 & $6,5636 \times 10^{-5}$ & 2168,9895 & 106,4160 & $\frac{2168,9895}{106,4160}$ \\
\hline 10 & 0,365 & $6,7472 \times 10^{-5}$ & 2052,5607 & 100,7038 & $\frac{2052,5607}{100,7038}$ \\
\hline 11 & 0,37 & $6,9333 \times 10^{-5}$ & 1943,8402 & 95,3697 & $\frac{1943,8402}{95,3697}$ \\
\hline 12 & 0,375 & $7,1220 \times 10^{-5}$ & 1842,2238 & 90,3841 & $\frac{1842,2238}{90,3841}$ \\
\hline
\end{tabular}

\subsection{Pengaruh Perubahan Luas Bukaan Katup pada Sistem Pengendalian Tinggi Muka Air}

Selanjunya, berdasarkan model-model tangki pada Tabel 2, dengan tidak melakukan perubahan parameter pengendali PID, hasil simulasi diperlihatkan pada Tabel 3. Dari Tabel 3 diketahui bahwa, untuk sistem kendali tinggi muka air dengan umpan balik single loop dan sistem pengendalian bertingkat, ketika luas lubang untuk air keluar dari tangki bertambah luas dari $a=$ $5,3434 \times 10^{-5} \mathrm{~m}^{2}$ menjadi $6,2040 \times 10^{-5} \mathrm{~m}^{2}$ sampai dengan $6,9333 \times 10^{-5} \mathrm{~m}^{2}$, error tinggi muka air terhadap setpoint masing-masing sebesar $0,03 \%$. Settling time untuk umpan balik single loop masing-masing selama 191 detik, 243 detik, 293 detik dan 352 detik. Sedangkan untuk sistem pengendalian bertingkat, masing-masing selama 163 detik, 190 detik, 212 detik dan 244 detik. Ketika katup dibuka sampai dengan maksimum sehingga luas bukaan katup 7,1220 x $10^{-5} \mathrm{~m}^{2}$ maka terjadi steady state error sebesar 3,17\%.

Apabila luas lubang untuk air keluar dari tangki berkurang dari $a=5,3434 \times 10^{5} \mathrm{~m}^{2}$, untuk umpan balik single loop steady stae error $> \pm 2 \%$, terjadi ketika luas bukaan katup menjadi 2,9172 x $10^{-5} \mathrm{~m}^{2}$, dengan error sebesar $-15,45 \%$. Sedangkan untuk sistem pengendalian bertingkat steady state error $> \pm 2 \%$ terjadi ketika luas bukaan katup menjadi 3,4236 $\times 10^{-5} \mathrm{~m}^{2}$, dengan error sebesar 
$-5,232 \%$. Settling time untuk umpan balik single loop mulai dari perubahan luas bukaan katup menjadi $4,5581 \times 10^{-5} \mathrm{~m}^{2}$ sampai dengan $3,1635 \times 10^{-5} \mathrm{~m}^{2}$, masing-masing diperoleh selama 397 detik, 1206 detik, 1631 detik, 2325 detik, 3659 detik dan 1749 detik. Sementara settling time untuk sistem pengendalian bertingkat, mulai dari perubahan luas bukaan katup menjadi 4,5581 $\mathrm{x}$ $10^{-5} \mathrm{~m}^{2}$ sampai dengan $3,5565 \times 10^{-5} \mathrm{~m}^{2}$, masing-masing diperoleh selama 382 detik, 2113 detik, 3996 detik dan 17556 detik.

Tabel 3. Error tinggi muka air dan setlling time akibat perubahan luas lubang untuk air keluar dari dalam tangki pada sistem pengendalian tinggi muka air.

\begin{tabular}{|c|c|c|c|c|c|c|c|}
\hline \multirow{3}{*}{ No } & \multirow{3}{*}{$\begin{array}{l}\text { Luas lubang } \\
\text { katup,a }\left(\mathrm{m}^{2}\right)\end{array}$} & \multicolumn{4}{|c|}{ Tinggi muka air, $h$} & \multicolumn{2}{|c|}{ Setlling Time } \\
\hline & & \multicolumn{2}{|c|}{ Single loop } & \multicolumn{2}{|c|}{$\begin{array}{c}\text { Pengendalian } \\
\text { bertingkat }\end{array}$} & \multirow{2}{*}{$\begin{array}{c}\text { Single loop } \\
\text { (detik) }\end{array}$} & \multirow{2}{*}{$\begin{array}{c}\begin{array}{c}\text { Pengendalian } \\
\text { bertingkat }\end{array} \\
\text { (detik) }\end{array}$} \\
\hline & & (meter) & $\begin{array}{c}\text { error } \\
(\%)\end{array}$ & (meter) & $\begin{array}{c}\text { error } \\
(\%)\end{array}$ & & \\
\hline 1 & $2,9172 \times 10^{-5}$ & 0,6927 & $-15,45$ & 0,8696 & $-44,93$ & - & - \\
\hline 2 & $3,1653 \times 10^{-5}$ & 0,5998 & 0,03 & 0.7386 & $-23,1$ & 1749 & - \\
\hline 3 & $3,4236 \times 10^{-5}$ & 0,5998 & 0,03 & 0,6314 & $-5,23$ & 3659 & - \\
\hline 4 & $3,5565 \times 10^{-5}$ & 0,5998 & 0,03 & 0,5998 & 0,03 & 2325 & 17556 \\
\hline 5 & $3,6920 \times 10^{-5}$ & 0,5998 & 0,03 & 0,5998 & 0,03 & 1631 & 3996 \\
\hline 6 & $3,8300 \times 10^{-5}$ & 0,5998 & 0,03 & 0,5998 & 0,03 & 1206 & 2113 \\
\hline 7 & $4,5581 \times 10^{-5}$ & 0,5998 & 0,03 & 0,5998 & 0,03 & 397 & 382 \\
\hline 8 & $6,2040 \times 10^{-5}$ & 0,5998 & 0,03 & 0,5998 & 0,03 & 191 & 163 \\
\hline 9 & $6,5636 \times 10^{-5}$ & 0,5998 & 0,03 & 0,5998 & 0,03 & 243 & 190 \\
\hline 10 & $6,7472 \times 10^{-5}$ & 0,5998 & 0,03 & 0,5998 & 0,03 & 293 & 212 \\
\hline 11 & $6,9333 \times 10^{-5}$ & 0,5998 & 0,03 & 0,5998 & 0,03 & 352 & 244 \\
\hline 12 & $7,1220 \times 10^{-5}$ & 0,5810 & 3,17 & 0,5810 & 3,17 &,- & ,- \\
\hline
\end{tabular}

\section{Kesimpulan}

Perubahan luas lubang untuk air keluar dari dalam tangki mengakibatkan perubahan penguatan dan konstanta waktu pada model tangki. Pada mini plant sistem kendali tinggi muka air di dalam tangki, menggunakan sistem pengendalian bertingkat atau umpan balik single loop, dengan tanpa mengubah parameter pengendali PID, pada sistem pengendalian umpan balik single loop diperoleh: $P=0,9547, I=0,0100, D=-31,8017$, pada sistem pengendalian bertingkat untuk LC diperoleh: $P=1,1105, \mathrm{I}=0,0088, D=-37,9007$ dan untuk FC diperoleh: $P=0$ dan $I=$ 0,1089. Maka berdasarkan hasil simulasi diperoleh: 1). Apabila katup untuk air keluar dari dalam tangki dibuka semakin luas dari 5,3434 x $10^{-5} \mathrm{~m}^{2}$ sampai dengan $6,9333 \times 10^{-5} \mathrm{~m}^{2}$, maka error tinggi muka air di dalam tangki terhadap set point sebesar 0,03\%. Apabila katup dibuka sampai dengan maksimum $7,1220 \times 10^{-5} \mathrm{~m}^{2}$ maka terjadi error sebesar 3,17\%;2). Apabila katup ditutup sehingga luas bukaan katup lebih kecil dari $5,3434 \times 10^{-5} \mathrm{~m}^{2}$, maka untuk sistem pengendalian bertingkat error tinggi muka air di dalam tangki terhadap set point $> \pm 2 \%$ terjadi ketika luas bukaan katup 3,4236 × $10^{-5} \mathrm{~m}^{2}$, dengan error sebesar $-5,232 \%$. Sedangkan untuk sistem pengendalian-single loop, error $> \pm 2 \%$ terjadi ketika luas bukaan katup $2,9172 \times 10^{-5} \mathrm{~m}^{2}$, dengan error sebesar -15,45\%; dan 3). Apabila luas bukaan katup bertambah luas, maka settling time untuk sistem pengendalian bertingkat lebih cepat daripada sistem pengendalian umpan balik single loop.

\section{Ucapan Terima Kasih}

Penulis mengucapkan terima kasih kepada seluruh staf dan manajemen Puslit KIM-LIPI atas dukungannya, sehingga pembuatan mini plant proses indutsri dapat diwujudkan. 


\section{Referensi}

[1] Cao HY, Deng N, "Design of water tank level cascade control system based on siemens S7-200," $11^{\text {th }}$ Conference on Industrial Electronics and Applications (ICIEA), IEEE, Hefei, China: 1926-1928, 2016.

[2] Setiawan IR, "Modeling and Simulation of Water Level Control in The Tank With Cascade Control System," International Journal of Engineering and Techniques. 15 (1), 69-78, 2019.

[3] Jang KL, "Regulating Control Valve at The Bottom of a Gravity-Drained Tank," Journal Chemical Engineering Education, American Institue of Chemical Engineers, 50 (4), 243250, 2016.

[4] Marsuda S, "Data-driven PID Gain Tuning for Liquid Level Control of a Single Tank Based on Disturbance Attenuation Fictitious Reference Iterative Tuning," $15^{\text {th }}$ International Conference on Control, Automation and Systems (ICCAS 2015), Busan. Korea: 16-20, 2015.

[5] Setiawan IR, "Penalaan PID Kontroler dengan Metode Ziegler-Nichols pada Sistem Pengendalian Bertingkat LC-FC," Skripsi Sarjana. Jakarta: Teknik Fisika Universitas Nasional, 2002.

[6] Setiawan IR, "Pembuatan Mini Plant Sebagai Simulator Instrumentasi untuk Pengukuran dan Pengendalian Proses dan SCADA di Industri," Pertemuan Presentasi Ilmiah-Kalibrasi Instrumentasi dan Metrologi (PPI-KIM), Kompleks Puspiptek Serpong: 101-124, 15-16 Juni 2010.

[7] Muller K, "Simulation and Process Control," Bremerhaven: Institute of Electrical Engineering and Control. University of Applied Sciences. 2003.

[8] Jagnade SA, Pandit RA, Bagde AR, "Modeling, Simulation and Control of Flow Tank System," International Journal of Science and Research, 4 (2), 657-669, 2015.

[9] Anderson AN, "Instrumentation for Process Measurement and Control," Third Edition. Pennsylvania: Chilton Company, 1970.

[10] Bequette WB, "Process Control: Modeling, Design, and Simulation," New Jersey: Prentice-Hall International Series in the Physical and Chemical Engineering Sciences, 2002

[11] Ogata K, "Modern Control Engineering. Fourth Edition,” New Jersey: Prentice-Hall, 2002.

[12] Setiawan IR, "Characterization of Simulator for Water Level Control in the Tank-Single Loop," International journal of engineering and techniques, 4 (1), 117-126, 2018. 